\title{
THE INFLUENCE OF ENGLISH SONGS TO IMPROVE STUDENTS' PRONUNCIATION IN TENTH GRADE OF VOCATIONAL HIGH SCHOOL
}

\author{
Liswanti $^{1}$, Siti Sumirah ${ }^{2}$ \\ ${ }^{1}$ IKIP Siliwangi \\ ${ }^{2}$ IKIP Siliwangi \\ 1'lizh.wanti@gmail.com, ${ }^{2}$ sitisumirah1602@gmail.com
}

\begin{abstract}
Pronunciation is an aspect that students in Indonesia should be known and und erstanding how to express each word in English. To make students easier to produce something in English, the writers take English song as a media to improve students' pronunciation. Beside of they can learn how to produce something in English language; they can gain the language or a new vocabulary. The research used pre experimental design with one group pre test and post test design which consists of 36 students as the sample. Then the data processed by SPSS 21. And the result of this research showed significance value was .00 and it is lower that the criteria .05 . It means the null hypothesis was rejected and the alternative hypothesis was accepted that English song is influence media in improving students' pronunciation.
\end{abstract}

Keywords: Pronunciation, Song, Language acquisition

\section{INTRODUCTION}

Nowadays every students in Indonesia love to sing English song. The song that famous nowadays are very attractive and make the people who heard it need to follow to sing like the singers. Some students who do not like to practice using English language are have different mindset about sing English song. Based on that fact, according to (Madsen, 1977) we can use a variety ways to evaluate the English pronunciation of students. Song is a way to asses students' pronunciation. They can express their feeling until understanding the lyrics meaning. They also can memorize the English vocabulary as quick as possible because of the tone in English songs.

When we use English songs as a media to practice their pronounce, they will try to be as good as singer do when they sing. They will try to pronounce the vocabulary same with the tone and what the singer did in that song. Because we teach the students in Vocational High School it means that they need the input in learning pronounce English. If we think that English is our second language, we must do filter hypothesis to make the English pronunciation effective. (Kaswan, 2014) state that if the students have high motivation, selfconfidence and low anxiety when perfom they will have a good input in English also when they need to have good pronunciation they need to controlled the speech organs which under the general control of muscles and brain.

Furthermore, pronunciation is important in learning English, not only when we speak to each other, the pronunciation when we are trying to sing something with some tone is important too to make a match with the song. (Madsen, 1977) says that the pronunciation test can be used as evaluation students' production, identification of the sounds, stress patterns, and intonations of English. But in this research the writer focused to what the singers' way to 
pronounce something, not depend of what teacher pronounce. With pronunciation and remembering something from the lyrics of song, the students are trying to learn vocabulary and listening too. If we training a lot, we can achieve perfect pronunciation in this second language, English.

Todays' pronounciation is improtant to understanding the context and meaning. For this research which based on some songs, the student try to understanding the lyrics. By learning pronounciation using songs they can at least measure the progress made on specific point of pronunciation, how advanced the students and how accurate the pronounce of students and the lyrics.

In this research we take a sample from a students in vocational high school which is include a type of English for specific purposes which address the unique needs of English language learners and users it can providing appropriate (Paltridge, 2013). According to (Harmer, 1998)The activities that we can follow is Engage-Activate-Study- that is the teacher ask the interested topic in song and then activate stage to doing something-singing. After that we study from the false lyric because it is important to correct mistake during the study exercise. With any kind of correction it is important to make criticsm.

Because writers scoring the students based on their pronouce, they need to memorize also the lyric of English song. The students should understand what are they going to remember. (Wallace, 2004)state that to memorize the lyric we can relate the things students want to learn to one another, or relate with our life.

Song is the basic thing we can hear from audio media. Using the audio media can make the teaching-learning process more unique contributions, because of audio media that can stimulate the imagination and music for physical acitivity (Heinich et al., 1996:174). Because we focus to the pronounce on songs, in here we will know the hearing-listening process too. The application of using English song is students can go back and repeat the song as often as necessary.

Relate to song, another audio material from the tapes are in sense of overpronounced, (Cunningsworth, 1994) stated that songs are weak forms are stressed and the ryhtym of speech distorted. Based on the explanation the writers want to figure out the influence of English songs to improve students' pronunciation especially in tenth grade of vocational high school.

The obejective of this research is to find out english songs to improve students' pronunciation in tenth grade of vocational high school

\section{METHOD}

The writers used quantitative as method in this research and pre experimental as a design. Quantitative research is focuses on how much or how many there is/are of a particular characteristic or item (Rasinger, 2011). Quantitative research can employ a number of different designs, one of which is usually selected at the outset depending on the kind of research question being investigated (Lewin, 2005) and the advantages of quantitative design is enable to compare the large number using a comparatively easy index. This research used pre experimental as a design. Furthermore, pre experimental or one-group pretest-posttest design involves three steps, the first is given pretest before the lesson is begun, pretest was implemented to find out the students' ability in pronunciation before the treatment the second is application of the experimental treatment and the last is given posttest after the lesson to 
know the students taught or to knowthe effect of English songs to improve students' pronunciation.

The reseach can be focused on the following research question: is English song can improve students' pronunciation in tenth grade of vocational high school? To answer the research question above the writers guided by following hypothesis:

Null Hypothesis $\left(\mathrm{H}_{0}\right) \quad$ : song can not improve students' pronunciation

Alternative Hypothesis $\left(\mathrm{H}_{\mathrm{a}}\right)$ : song can improve students' pronunciation

\section{RESULTS AND DISCUSSION}

\section{Results}

To know the result of pre-test and post-test the writers makes the table of students. As an ethic code, the writers do not mention the students' names, but their scores are as follows:"

Table 1. The result of pretest and posttest

\begin{tabular}{|c|c|c|}
\hline STUDENT & PRETEST & POSTTEST \\
\hline 1 & 45 & 87 \\
\hline 2 & 45 & 80 \\
\hline 3 & 60 & 90 \\
\hline 4 & 40 & 81 \\
\hline 5 & 50 & 85 \\
\hline 6 & 40 & 84 \\
\hline 7 & 45 & 90 \\
\hline 8 & 55 & 92 \\
\hline 9 & 40 & 88 \\
\hline 10 & 45 & 83 \\
\hline 11 & 48 & 90 \\
\hline 12 & 50 & 90 \\
\hline 13 & 45 & 89 \\
\hline 14 & 35 & 85 \\
\hline 15 & 55 & 90 \\
\hline 16 & 45 & 80 \\
\hline 17 & 35 & 85 \\
\hline 18 & 50 & 80 \\
\hline 19 & 50 & 87 \\
\hline 20 & 55 & 90 \\
\hline 21 & 50 & 88 \\
\hline 22 & 45 & 80 \\
\hline 23 & 50 & 85 \\
\hline 24 & 70 & 98 \\
\hline 25 & 50 & 80 \\
\hline 26 & 60 & 85 \\
\hline 27 & 58 & 88 \\
\hline 28 & 50 & 85 \\
\hline
\end{tabular}




\begin{tabular}{lll}
\hline 29 & 70 & 90 \\
30 & 50 & 87 \\
31 & 50 & 85 \\
32 & 50 & 85 \\
33 & 48 & 85 \\
34 & 58 & 95 \\
35 & 60 & 87 \\
36 & 60 & 80 \\
\hline
\end{tabular}

Table 2. One-Sample Kolmogorov-Smirnov Test

\begin{tabular}{|c|c|c|c|}
\hline & & Pretest & Posttest \\
\hline \multirow{3}{*}{$\begin{array}{l}\text { N } \\
\text { Normal Parameters }{ }^{a, b}\end{array}$} & & 36 & 36 \\
\hline & Mean & 42.1111 & 86.3611 \\
\hline & $\begin{array}{l}\text { Std. } \\
\text { Deviation }\end{array}$ & 7.32814 & 4.33031 \\
\hline Extreme & Absolute & .197 & .127 \\
\hline \multirow[t]{2}{*}{ Differences } & Positive & .197 & .123 \\
\hline & Negative & -.109 & -.127 \\
\hline \multicolumn{2}{|l|}{ Test Statistic } & .197 & .127 \\
\hline \multicolumn{2}{|l|}{ Asymp. Sig. (2-tailed) } & $.001^{\mathrm{c}}$ & $.155^{\mathrm{c}}$ \\
\hline
\end{tabular}

a. Test distribution is Normal.

b. Calculated from data.

c. Lilliefors Significance Correction.

See the results above, on Post Test Absolute value 0.127. When compared with smirnov table in sample $\mathrm{N}=36$ that is 0,197 , then $0,127<0,197$ which mean normal distribution data. This is evidenced by the results of probability test on SPSS that is seen on Asymp value. Sig. (2 tailed) the value is 0.155 where $>0.05$ which means the data is normally distributed.

Table 3. Paired Samples Test

\begin{tabular}{|c|c|c|c|c|c|c|c|c|}
\hline & \multicolumn{5}{|c|}{ Paired Differences } & \multirow[b]{3}{*}{$\mathrm{t}$} & \multirow[b]{3}{*}{ df } & \multirow{3}{*}{$\begin{array}{l}\text { Sig. } \\
(2- \\
\text { tailed })\end{array}$} \\
\hline & \multirow[b]{2}{*}{ Mean } & \multirow{2}{*}{$\begin{array}{l}\text { Std. } \\
\text { Deviation }\end{array}$} & \multirow{2}{*}{$\begin{array}{l}\text { Std. } \\
\text { Error } \\
\text { Mean }\end{array}$} & \multicolumn{2}{|c|}{$\begin{array}{l}95 \% \text { Confidence } \\
\text { Interval of the } \\
\text { Difference }\end{array}$} & & & \\
\hline & & & & Lower & Upper & & & \\
\hline $\begin{array}{l}\text { Pretest } \\
\text { Posttest }\end{array}$ & -36.02778 & 7.17729 & 1.19622 & -38.45622 & -33.59933 & $\begin{array}{l}- \\
30.118\end{array}$ & 35 & .000 \\
\hline
\end{tabular}


Table 3 showed that Asymp.Sig value was .000, with the level of significance level was .05, and it means that significance value was lower than the significance level. In other word, the null hypothesis was rejected. Thus, English song was influence to teach pronunciation.

\section{Discussion}

The objective of the research is to investigate whether the students who got the treatment using English songs have better in pronunciation ability than students without treatment using English songs. Based on the table above, the mean of .pretest is 42.1111 and mean of posttest is 86.3611 it means that the mean of posttest was bigger than pretest and in table 3 showed that sig (2-tailed) is .000 is smaller than .05 , can be conclude that the hypothesis $\left(\mathrm{H}_{\mathrm{a}}\right)$ was accepted. In other words, English song can improve students' pronunciation in tenth grade of vocational high school

\section{CONCLUSION}

Based on the explanation in result and discussion, we can conclude that English songs are improve the students ability in pronounce English language and the English songs are made a motivation for each students to perform as well as they can do. Foreign language can be acquist if we learn English pronounciation from songs. Relate to the data of SPSS that significance value (.00) was lower than the significance level (.05) so the English songs is an influence media to improve English pronounciation ability.

\section{ACKNOWLEDGMENTS}

Thanks Allah SWT for entire blessing in finished this article. During completing the article the writer obtained many help, suggestions, and motivations from many people. For that reason, the writer would like to express the gratitude to: head of IKIP Siliwangi Bandung, head of English education study program and to supervisor. 


\section{REFERENCES}

Cunningsworth, A. (1994). Evaluating and Selecting EFL Teaching Materials. London: Heinemann Educational Books.

Harmer, J. (1998). How to Teach English. England: Pearson Education Limited.

Heinich Robert, Michael Molenda, James D. Russel, Sharon E. Smaldino. (1996). Instructional Media and Technologies for Learning. United States: Prentice Hall.

Kaswan, D. S. (2014). Language Acquisition. Jakarta: Dapur Buku.

Lewin, C. (2005). Research Method in the Social Science. London: Sage Publications.

Madsen, H. S. (1977). Techniques in Testing. New York: Oxford University Press.

Paltridge, B. (2013). The Handbook of English for Specific Purposes. UK: Wiley-Blackwell.

Rasinger, S. M. (2011). Research Method in Linguistics. India: British Library Cataloguingin-Publication Data.

Wallace, M. J. (2004). Study Skill in English. UK: Cambridge Univercity Press. 